\title{
Bradyrhizobia associated with Laburnum anagyroides, an exotic legume grown in Poland
}

\author{
Ewa Sajnaga ${ }^{1}$ (D) $\cdot$ Monika Elżbieta $\operatorname{Jach}^{2}$ (D) \\ Received: 10 December 2019 / Accepted: 24 February 2020 /Published online: 7 March 2020 \\ (C) The Author(s) 2020
}

\begin{abstract}
We isolated 18 rhizobial strains from root nodules of a leguminous shrub Laburnum anagyroides (common laburnum) grown in Southeast Poland as an exotic plant. With the use of BOX-PCR fingerprinting, the isolates were clustered into 2 main groups and one separate lineage, which was congruent with the ITS-RFLP results. The phylogenetic trees constructed based on 16S rRNA and combined $a t p D$, dnaK, $g \ln A$, and recA gene sequence data separated the representative strains into three evolutionary lineages within the Bradyrhizobium jicamae supergroup, with Bradyrhizobium algeriense and Bradyrhizobium valentinum as the closest relatives. The nodA and nifH gene phylogenies proved that the L. anagyroides symbionts carry a symbiotic gene variant known as Clade IV, representing the symbiovar retamae. Phenotypic characteristics of the isolates and reference strains are also reported. Our study of the rhizobia nodulating L. anagyroides growing in Poland complements earlier few findings on the symbiotic associations of this Genisteae species.
\end{abstract}

Keywords Bradyrhizobium $\cdot$ Laburnum anagyroides $\cdot$ Symbiosis $\cdot$ Phylogeny $\cdot$ MLSA

\section{Introduction}

Bacteria of the genus Bradyrhizobium (Jordan 1982) and at least 11 other rhizobial genera participate in the process of $\mathrm{N}_{2^{-}}$ fixing symbiosis with legume plants classified in the family Fabaceae (Lindström et al. 2015; Shamseldin et al. 2017). They can establish symbiosis with all major legume lineages of Fabaceae spp. and even non-legume Parasponia andersonii, which suggests that bradyrhizobia may have been the ancestor of all rhizobia (Hungria et al. 2015; Parker 2015). Bradyrhizobium communities are also abundant in many soils where legumes are absent, often acting as endophytes of different plants (Vanlnsberghe et al. 2015). The studies have revealed that the genus Bradyrhizobium is separated into

Electronic supplementary material The online version of this article (https://doi.org/10.1007/s13199-020-00668-x) contains supplementary material, which is available to authorized users.

Monika Elżbieta Jach

monijach@kul.lublin.pl

1 Laboratory of Biocontrol, Application and Production of EPN, Centre for Interdisciplinary Research, The John Paul II Catholic University of Lublin, Konstantynów 1J, 20-708 Lublin, Poland

2 Department of Molecular Biology, The John Paul II Catholic University of Lublin, Konstantynów 1i, 20-708 Lublin, Poland seven lineages, including symbiotic as well non-symbiotic bacteria (Avontuur et al. 2019; Ormeño-Orrillo and Martínez-Romero 2019). A large number of species in Bradyrhizobium has been recognized, however the list of species in this genus will probably be still growing due to the rapid development of molecular tools and the huge diversity of this genus (Stepkowski et al. 2018; de Lajudie et al. 2019).

Given the widespread deforestation and the need for increasing soil fertility and quality of poorly productive and anthropogenically affected soils, more importance is now being given to woody and shrubby legumes due to their beneficial properties (Adams et al. 2010; Castro et al. 2017). Laburnum anagyroides is a large shrub from the tribe Genisteae originating from Southern and Central Europe. The partnership of $L$. anagyroides with $\mathrm{N}_{2}$-fixing rhizobia gives this plant an ability to grow in nutrient deficient soils. The common laburnum was first introduced in Poland in 1805 and is now found in many parks, open spaces, and gardens as a decorative plant. Although this plant is widespread in Poland, there have been no studies characterizing its symbiotic bacteria. A few earlier studies identified the Spanish L. anagyroides microsymbionts as Bradyrhizobium canariense (Ruiz-Díez et al. 2009) and these from Belgium and Croatia as Bradyrhizobium spp. (De Meyer et al. 2011; Parker 2015); however, further investigations are necessary to provide better understanding of the $L$. anagyroides 
microsymbiont diversity and to confirm their positive effects on plant growth.

\section{Materials and methods}

\subsection{Isolation of rhizobia from root nodules}

The bacterial isolates were obtained from effective (pink) root nodules of $L$. anagyroides Medic. plants growing in urban green areas in South-Eastern Poland (Table 1). The root systems of 50 plants were examined and about 850 nodules were obtained for further analysis. The bacteria were isolated from surface-sterilized nodules and after sterilization prepared and plated on solid Yeast Mannitol Agar (YMA) as previous described (Somasegaran and Hoben 1994). The bacteria isolated from the nodules were purified by streaking to obtain single colonies and pure cultures were used in further experiments.

\subsection{Phenotypic analysis}

The culture characteristics were assessed in YM Broth (YMB) or on YMA plates. Mean generation times were determined with the spectrophotometric method (480 and $600 \mathrm{~nm}$ ) after incubation of the bacteria in YM broth at $28^{\circ} \mathrm{C}$ and $\mathrm{pH} 7.0$. The growth temperature was determined by incubation of the cultures in YMA pH 7.0 from $4{ }^{\circ} \mathrm{C}$ to $45^{\circ} \mathrm{C}$. The growth $\mathrm{pH}$ range was determined by incubation of the cultures in YMA at $28^{\circ} \mathrm{C}$ and $\mathrm{pH}$ from 4.0 to 10.0 . Basal medium $\mathrm{pH}$ was adjusted to required $\mathrm{pH}$ with $1 \mathrm{M} \mathrm{HCl}$ or $1 \mathrm{M} \mathrm{NaOH}$. The salt tolerance of the isolates was assayed by adding $0.5,1,2$, and $3 \% \mathrm{NaCl}$ to the medium. Utilization of 11 different amino acids or assimilation of 13 various carbohydrates at $1 \%(w /$ $v$ ) as a sole nitrogen or carbohydrate sources was investigated on a modified liquid YM broth, in which yeast extract or mannitol (respectively) was replaced by the different amino acids or the respective carbohydrates. The intrinsic antibiotic resistance was tested on YMA plates containing 14 different antibiotics at the appropriate dilution.

\subsection{Plant nodulation tests}

The plant test was carried out as previous described (Hoagland and Arnon 1950; Vincent 1970; Somasegaran and Hoben 1994). Briefly, the seeds were sterilized, prepared, germinated and planted on a solid N-free Hoagland's medium (one per jar). After 7-14 days, healthy seedlings were inoculated with $0.5 \mathrm{U}$ McFarland standard $\left(1.5 \times 10^{8} \mathrm{CFU} / \mathrm{ml}\right)$ cells of an individual strain grown in liquid YM broth, pelleted, and suspended in sterile water. The plants were grown for a minimum of 3 and a maximum of 6 weeks in a greenhouse under natural light supplemented with artificial light (14 h day/10 h night, at $24 / 19^{\circ} \mathrm{C}$ ). Then, the plants were examined for the presence of nodules, their number, size, and color, as well as appearance of the aerial parts. The tests were performed in triplicate and compared with the negative control (noninoculated plants) and positive control (reinoculated L. anagyroides).

\subsection{Rep-PCR fingerprinting, ITS-RFLP, and gene sequencing}

The genomic DNA was isolated from the bacteria using a Genomic Mini AX Bacteria Spin Kit (A\&A Biotechnology). For rep-PCR fingerprinting, DNA was amplified by PCR with the primer BOXA 1R (Versalovic et al. 1994) as described by Kaschuk et al. (2006). To confirm the reproducibility of the BOX-PCR fingerprinting protocol, the isolates were analyzed independently three times. A computer cluster analysis of polymorphic bands was carried out using a simple matching
Table 1 Bradyrhizobium strains from root nodules of L. anagyroides considered in this study, their geographic origin and classification based on BOX-PCR and ITS-RFLP analysis

\begin{tabular}{lll}
\hline Strain & Geographic origin & $\begin{array}{l}\text { BOX-PCR and ITS-RFLP } \\
\text { genotype }\end{array}$ \\
\hline Ba-Z92, Z93, Z95, Z97, Z98, Z99, Z90 & $\begin{array}{l}\text { Lublin, estate greenery } \\
51^{\circ} 14^{\prime} 23^{\prime \prime} \mathrm{N} 22^{\circ} 30^{\prime} 52^{\prime \prime} \mathrm{E}\end{array}$ & $\mathrm{I}$ \\
Lublin, estate greenery & \\
& $51^{\circ} 14^{\prime} 24^{\prime \prime} \mathrm{N} 22^{\circ} 31^{\prime} 00^{\prime \prime} \mathrm{E}$ & \\
& Lublin, park & \\
Ba-Z88 & $51^{\circ} 14^{\prime} 19^{\prime \prime} \mathrm{N} 22^{\circ} 30^{\prime} 52^{\prime \prime} \mathrm{E}$ & \\
& Sandomierz, botanical garden & \\
Ba-Z30, Z44 & $50^{\circ} 40^{\prime} 28^{\prime \prime} \mathrm{N} 21^{\circ} 44^{\prime} 26^{\prime \prime} \mathrm{E}$ & \\
Ba-Z40, Z45, Z47 & Sandomiarz, botanical garden & II \\
& $50^{\circ} 40^{\prime} 28.5^{\prime \prime} \mathrm{N} 21^{\circ} 44^{\prime} 23^{\prime \prime} \mathrm{E}$ & III \\
Ba-Z102 & Lublin, park & \\
& $51^{\circ} 14^{\prime} 28.5^{\prime \prime} \mathrm{N} 22^{\circ} 30^{\prime} 35^{\prime \prime} \mathrm{E}$ & \\
\hline
\end{tabular}

The representative strains used for further phylogenetic analysis are marked in bold 
coefficient and the UPGMA method in the NTSYSpc program (Sneath and Sokal 1973). PCR amplifications of the 16S-23S rRNA ITS were done using primers FGPS 1490 and FPGS 132 previously described by Laguerre et al. (1996). The PCR products were digested separately with MboI, MspI, Hin 6I, HinfI, TaqI, AluI, and RsaI endonucleases and restriction fragments were separated by electrophoresis in $3 \%$ agarose gels in TBE buffer. The isolates that had identical RFLP patterns were appointed to the same rDNA genotype. The housekeeping genes coding for recombinase A (recA), $70 \mathrm{kDa}$ chaperone protein $($ dnaK $)$, ATP synthase subunit beta $(a t p D)$, and glutamine synthetase II $(g \ln I I)$ were amplified as described by Stępkowski et al. (2005). 16S rDNA and symbiotic genes nifH and nodA coding for dinitrogenase reductase and $\mathrm{N}$-acyltransferase nodulation protein A, respectively, were amplified as described earlier (Kalita and Małek 2017). The PCR products were ligated into plasmid pJET1.2 (Thermo Fisher Scientific) according to the manufacturer's instructions and transformed in E. coli XL1Blue using a standard method. The inserts of recombinant clones were sequenced in Genomed (Poland).

\subsection{Phylogenetic analysis}

Gene sequences obtained in this study were compared to GenBank nucleotide sequences using the BLAST program. Sequence alignments were created using ClustalW at default configuration and corrected manually. Sequence identity values based on obtained multiple alignments were calculated using BioEdit software. Phylogenetic trees were inferred using maximum likelihood (ML) method in MEGA 6.06 (Tamura et al. 2013). The best-fit nucleotide substitution model for each tree was determined in MEGA 6.06. To determine the statistical support for the branches of the phylogenetic trees, 1000 bootstrap replicates of the data were analyzed.

\section{Results}

\subsection{Isolation and nodulation tests}

In this study, 18 rhizobial strains were isolated from root nodules sampled from $L$. anagyroides grown as a decorative plant in two cities of Southeast Poland (Table 1). All the strains were able to nodulate $L$. anagyroides plants efficiently. As a result, the big dark green plants developed an average of 8-25 pink root nodules per plant 3-6 weeks after the inoculation with the studied isolates (Fig. 1). These plants were clearly different from the small non-inoculated control plants. Three representative isolates $\mathrm{Ba}-\mathrm{Z} 45, \mathrm{Ba}-\mathrm{Z} 95$, and $\mathrm{Ba}-\mathrm{Z} 102$ also induced effective nodules on Colutea arborescens and Lupinus polyphyllus (red nodules). No symbiosis was established with Glycine max.
3.2 BOX-PCR and RFLP analysis of the 16S-23S rDNA ITS

After DNA amplification with the BOX A1R primer, genomic DNA profiles consisting of 20 polymorphic bands sized from 200 to $2000 \mathrm{bp}$ were obtained for all 18 strains. For some isolates the BOX A1R-PCR generated identical DNA profiles. Figure 2 shows a dendrogram based on the analysis of BOX A1R-PCR products, which were clustered at the similarity level of $41 \%$. At $70 \%$ similarity, the studied strains grouped into two rep-PCR clusters consisting of 14 and 3 strains and 1 independent lineage (Fig. 2). Based on the 16S-23S rDNA ITS restriction fragment length polymorphism (RFLP) analysis, 3 ITS genotypes were distinguished among the 18 isolates (Table 1). Three isolates that represent different ITS RFLP and BOX-PCR types were used in the subsequent characterization.

\subsection{Phenotypic characterization of $L$. anagyroides nodule endosymbionts}

The studied strains were Gram-negative non-spore-forming rods. The appearance of non-mucous white colonies $(<1.5 \mathrm{~mm}$ size $)$ on the YMA plates incubated at $28^{\circ} \mathrm{C}$ after 5-7 days and an alkaline reaction on the YMA plates supplied with bromothymol blue suggested that the studied bacterial isolates belong to the genus Bradyrhizobium (Adams et al. 2010). The optimal growth temperature of studied strains was between $28^{\circ} \mathrm{C}$ and $35^{\circ} \mathrm{C}$. The optimum $\mathrm{pH}$ for growth ranged from 7.0 to 8.0. The isolates utilized erythritol, D-galactose, glycerol, D-glucose, mannitol, sorbitol, starch, stevia, sucrose, Tween, and xylitol as carbon sources. Ba-Z102 strains also utilized xylose and Dfructose as a carbon source. All tested strains assimilated cysteine, histidine, isoleucine, leucine, proline, and serine, but not lysine and arginine. Additionally, two isolates, BaZ95, and Ba-Z102, also assimilated methionine, valine, and tyrosine as nitrogen sources. All studied microsymbionts were resistant to cefoxitin $\left(110 \mu \mathrm{g} \mathrm{mL} \mathrm{m}^{-1}\right)$, ceftazidine $\left(230 \mu \mathrm{g} \mathrm{mL}^{-1}\right)$, clindamycin $\left(2 \mu \mathrm{g} \mathrm{mL}^{-1}\right)$, cloxacillin $\left(5 \mu \mathrm{g} \mathrm{mL}^{-1}\right)$, meropenem $\left(10 \mu \mathrm{g} \mathrm{mL}^{-1}\right)$, nalidixic acid $\left(30 \mu \mathrm{g} \mathrm{mL}^{-1}\right)$, and piperacillin $\left(30 \mu \mathrm{g} \mathrm{mL}^{-1}\right)$. The Ba-Z45 and $\mathrm{Ba}-\mathrm{Z} 95$ strains were sensitive to streptomycin $\left(10 \mu \mathrm{g} \mathrm{mL}^{-1}\right)$. Ba-Z45 and Ba-Z102 did not grow in the presence of ampicillin $\left(50 \mu \mathrm{g} \mathrm{mL}^{-1}\right)$, amoxicillin $\left(25 \mu \mathrm{g} \mathrm{mL}^{-1}\right)$ and erythromycin $\left(15 \mu \mathrm{g} \mathrm{mL}^{-1}\right)$. Only BaZ45 isolate did not grow in the presence of doxycycline $\left(30 \mu \mathrm{g} \mathrm{mL}^{-1}\right)$ and tetracycline $\left(15 \mu \mathrm{g} \mathrm{mL}^{-1}\right)$. Differential characteristics of the representative $L$. anagyroides isolates in comparison to the relevant reference species of the Bradyrhizobium genus are described in Table 2. 
Fig. 1 Photos of Laburnum anagyroides nodulated roots: a. non-inoculated plant; $\mathbf{b}$. inoculated plant; c. close up of the root systems with nodules
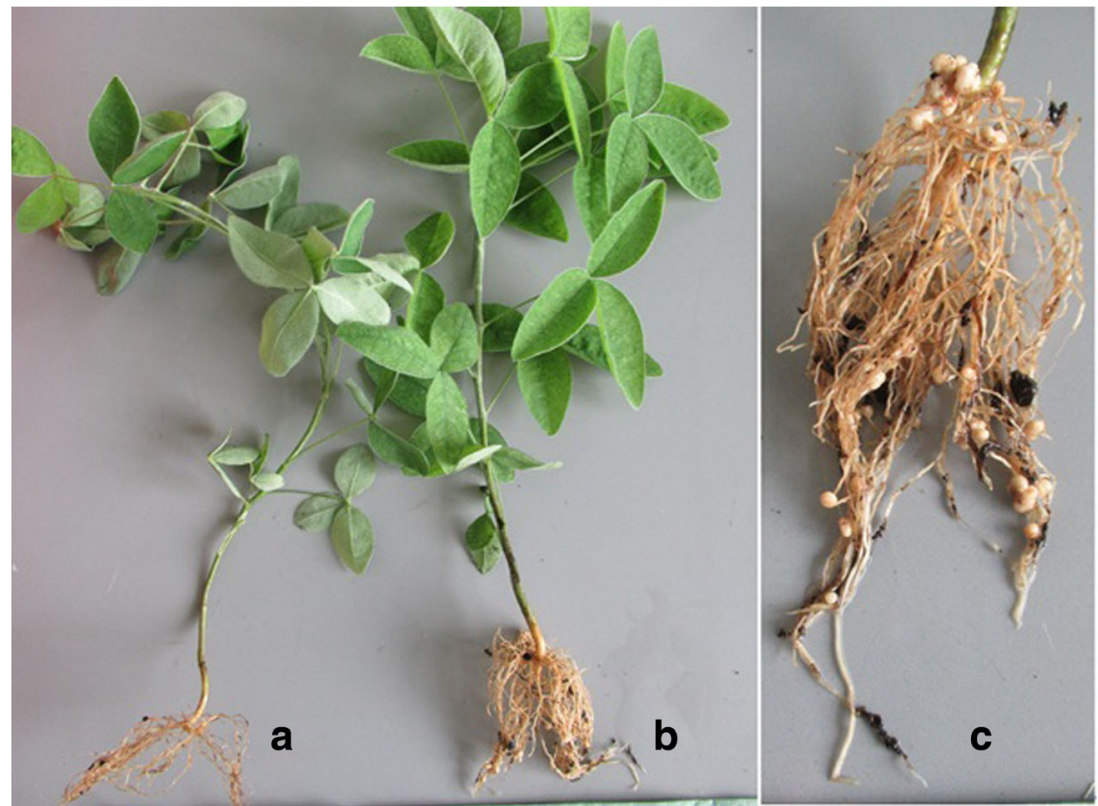

\subsection{S rRNA gene phylogeny}

The sequences of $16 \mathrm{~S}$ rDNA (1253 bp) isolates Ba-Z45, BaZ95, and Ba-Z102 shared 99.6-100\% sequence similarity with each other. The analyzed sequences were most similar to the $16 \mathrm{~S}$ rDNA sequence reported for Bradyrhizobium algeriense $\mathrm{RST} 9^{\mathrm{T}}$ displaying 99.6-100\% identity. Likewise, several 16S rDNA sequences of a type strain from other Bradyrhizobium species exhibited high identity values (99.5-99.9\%) to $16 \mathrm{~S}$ rDNA sequences of the studied isolates, including Bradyrhizobium icense LMTR $13^{\mathrm{T}}$, Bradyrhizobium erythrophlei CCBAU $53325^{\mathrm{T}}$, Bradyrhizobium embrapense
SEMIA $6208^{\mathrm{T}}$, and Bradyrhizobium viridifuturi SEMIA $690^{\mathrm{T}}$. Based on the phylogenetic analysis of $16 \mathrm{~S}$ rDNA gene sequences, the isolates were clustered with the type strains representing the Bradyrhizobium jicamae supergroup (Fig. 3).

\subsection{Housekeeping gene phylogeny}

The sequences of atpD (491 bp), dnaK (236 bp), glnII (480 bp), and recA (412 bp) of the representative isolates exhibited 94-96\%, 98-99\%, 96-98\%, and 94-95\% similarity to each other, respectively. Compared to the type strains of recognized Bradyrhizobium species, these sequences were

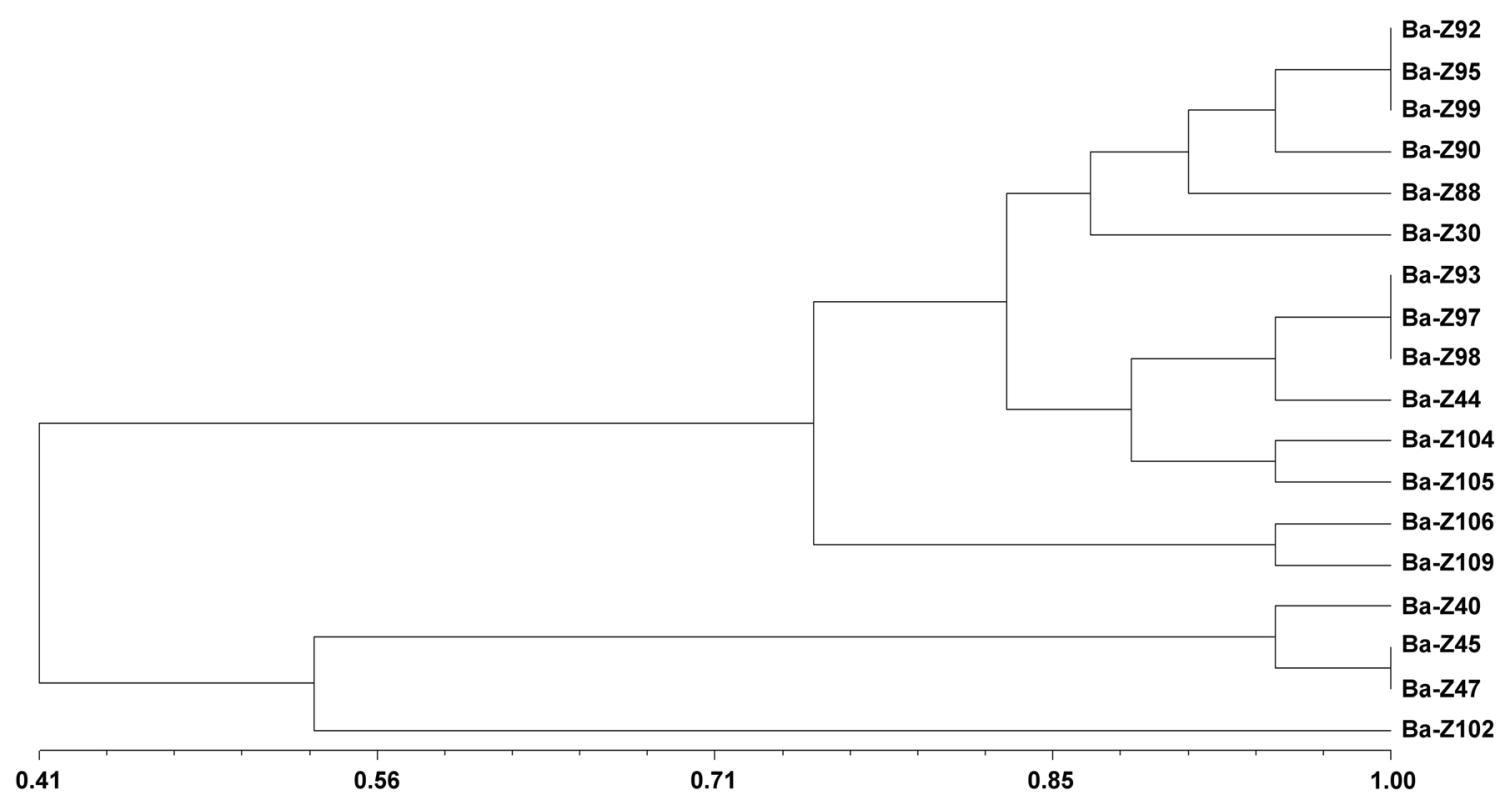

Fig. 2 UPGMA dendrogram showing the genomic diversity of L. anagyroides symbionts based on BOX-PCR patterns. The scale of the dendrogram presents the similarity rate of electrophoresis band profiles 
Table 2 Differential characteristics of Bradyrhizobium strains isolated from $L$. anagyroides and related species in the genus

\begin{tabular}{|c|c|c|c|c|c|c|}
\hline Characteristic/strains $\mathrm{s}^{\mathrm{a}}$ & 1 & 2 & 3 & $4^{\mathrm{b}}$ & $5^{\mathrm{c}}$ & 6 \\
\hline Generation time (h) in YM broth & $8-9$ & $8-9$ & $9-10$ & $>20$ & $11-12$ & $>6$ \\
\hline \multicolumn{7}{|l|}{ Growth at: } \\
\hline $1.0 \% \mathrm{NaCl}$ & - & - & - & - & + & + \\
\hline $\mathrm{pH} 4.0$ & $\mathrm{w}$ & - & $\mathrm{w}$ & + & - & + \\
\hline pH 5.0 & + & + & + & ND & ND & + \\
\hline pH 8.0 & + & + & + & ND & + & + \\
\hline pH 9.0 & + & + & + & ND & + & + \\
\hline $\mathrm{pH} 10.0$ & $\mathrm{w}$ & $\mathrm{w}$ & $\mathrm{w}$ & - & + & $t^{\mathrm{d}}$ \\
\hline $37^{\circ} \mathrm{C}$ & + & + & + & - & - & + \\
\hline \multicolumn{7}{|l|}{ Resistance to $\left(\mu \mathrm{g} / \mathrm{mL}^{-1}\right)$ : } \\
\hline Ampicillin (50) & - & + & - & + & ND & + \\
\hline Erythromycin (50) & - & + & - & - & - & + \\
\hline Streptomycin (10) & - & - & + & - & - & - \\
\hline Tetracycline (5) & - & + & + & + & - & + \\
\hline \multicolumn{7}{|l|}{ Utilization of carbon sources: } \\
\hline D-galactose & + & $\mathrm{w}$ & + & + & ND & + \\
\hline D-glucose & + & $\mathrm{w}$ & + & + & ND & + \\
\hline D-fructose & - & - & + & + & + & + \\
\hline Mannitol & + & + & + & + & + & + \\
\hline Sucrose & + & + & + & - & - & + \\
\hline \multicolumn{7}{|l|}{ Utilization of nitrogen sources: } \\
\hline Cysteine & + & + & + & - & ND & + \\
\hline Histidine & + & - & + & + & ND & + \\
\hline L-proline & + & + & + & ND & + & + \\
\hline
\end{tabular}

+: growth or resistant; -: no growth or sensitive; w: weak growth or variable; ND: not determined

${ }^{\text {a }}$ Species/strains: L. anagyroides nodule isolates: 1. Ba-Z45; 2. Ba-Z95; 3. Ba-Z102; 4. B. algeriense RST89 ${ }^{\mathrm{T}}$; 5. B. icense $\mathrm{LMTR}^{\mathrm{T}}$; 6. B. elkanii USDA $76^{\mathrm{T}}$

${ }^{\mathrm{b}}$ Ahnia et al. 2018; ${ }^{\mathrm{c}}$ Durán et al. 2014; ${ }^{\mathrm{d}}$ This result is not consistent with that reported by Durán et al. 2014

most similar to those of $B$. algeriense RST89 ${ }^{\mathrm{T}}$, showing 9596\%, 97-97\%, 96-98\%, and 92-95\% similarity, respectively (Fig. S1-S4). Concatenated sequences of the recA, dnaK, $a t p D$, and $g \ln A$ genes $(1619 \mathrm{bp})$ for the tested isolates of $L$. anagyroides shared similarities with each other in a range of $95-96 \%$, likewise with B. algeriense RST $89^{\mathrm{T}}$. In the phylogenetic tree based on the concatenated sequences of the housekeeping genes, the isolates were clustered in one of a well-supported branch comprising B. algeriense $\mathrm{RST} 89^{\mathrm{T}}$ and Bradyrhizobium valentinum LmjM3 $^{\mathrm{T}}$ (Fig. 4).

\section{$3.6 \operatorname{nod} A$ and nifH gene phylogeny}

The nodA sequences of the L. anagyroides bradyrhizobia isolated in Poland shared $98 \%$ similarity to each other and clustered with those of B. algeriense RST89 ${ }^{\mathrm{T}}$, B. valentinum
LmjM3 ${ }^{\mathrm{T}}$, Bradyrhizobium retamae $\mathrm{R} 019^{\mathrm{T}}$, B. icense LMTR $13^{\mathrm{T}}$, and Bradyrhizobium lablabi CCBAU $23086^{\mathrm{T}}$ displaying 97-99\%, 96-97\%, 96-97\%, 95-97\%, and 9395\% sequence identity, respectively (Fig. 5). The nifH gene sequences of three tested isolates shared $99 \%$ similarity. In the nifH phylogram, the L. anagyroides microsymbionts are grouped together with $B$. algeriense $\mathrm{RST} 89^{\mathrm{T}}$ and B. valentinum $\mathrm{LmjM}^{\mathrm{T}}$, displaying $99-100 \%$ and $99 \%$, sequence identity, respectively (Fig. 6).

\section{Discussion}

The bacterial strains analyzed here are rhizobia obtained from nodules of $L$. anagyroides growing in Poland. To get a tentative insight into the genetic diversity of the isolates we performed rep-PCR fingerprinting with the BOX A1R primer, which had been shown to be a reliable typing method used for differentiation and preliminary characterization of rhizobial strain collections (Koeuth et al. 1995; Kaschuk et al. 2006; Menna et al. 2009; Cardoso et al. 2017). The BOX-PCR analysis provided the basis for separating the isolates into three distinct groups (Fig. 2, Table 1). In order to confirm the diversity pattern of the tested strains obtained by rep-PCR, PCRbased 16S-23S rDNA RFLP analysis was carried out. Previous studies have shown relevant results for searching nodule bacterial biodiversity, and selection of strains for further experiments can be provided by restriction analysis of the ITS region (e.g. Menna et al. 2009; Sachs et al. 2009; Yao et al. 2014). We identified three different RFLP-PCR profiles of $16 \mathrm{~S}-23 \mathrm{~S}$ rDNA in the analysis of all tested $L$. anagyroides nodule isolates, corroborating the rep-PCR results (Table 1).

Phenotypic characterization of $L$. anagyroides nodule isolates was performed by assessment of properties that were previously described as useful for Bradyrhizobium species differentiation (Chang et al. 2011; Guerrouj et al. 2013). The three $L$. anagyroides strains Ba-Z45, Ba-Z95, and Ba-Z102, i.e. representatives of each rep-PCR and ITS-RFLP cluster, did not behave phenotypically as a homogenous group (Table 2). In contrast to strains of $B$. algeriense RST89 (Ahnia et al. 2018) and B. icense LMTR13 ${ }^{\mathrm{T}}$ (Durán et al. 2014), all isolates studied had a shorter generation time, grew well at $37{ }^{\circ} \mathrm{C}$ and $42{ }^{\circ} \mathrm{C}$ but poorly at $45{ }^{\circ} \mathrm{C}$, and utilized sucrose as the sole carbon source (Table 2).

In prokaryotes, the 16S rRNA gene sequence is a key phylogenetic marker, in most cases allowing fast identification of new isolates to at least the genus level (Stackebrandt et al. 2002; Tindall et al. 2010). It is generally accepted that nearly complete 16S rRNA gene sequence identity of two bacterial strains $<95 \%$ and $<98.7 \%$ is strong evidence for distinct genera and distinct species, respectively (Yarza et al. 2014). To classify our isolates to the genus level, we sequenced the $16 \mathrm{~S}$ rRNA gene from three representative strains. The 


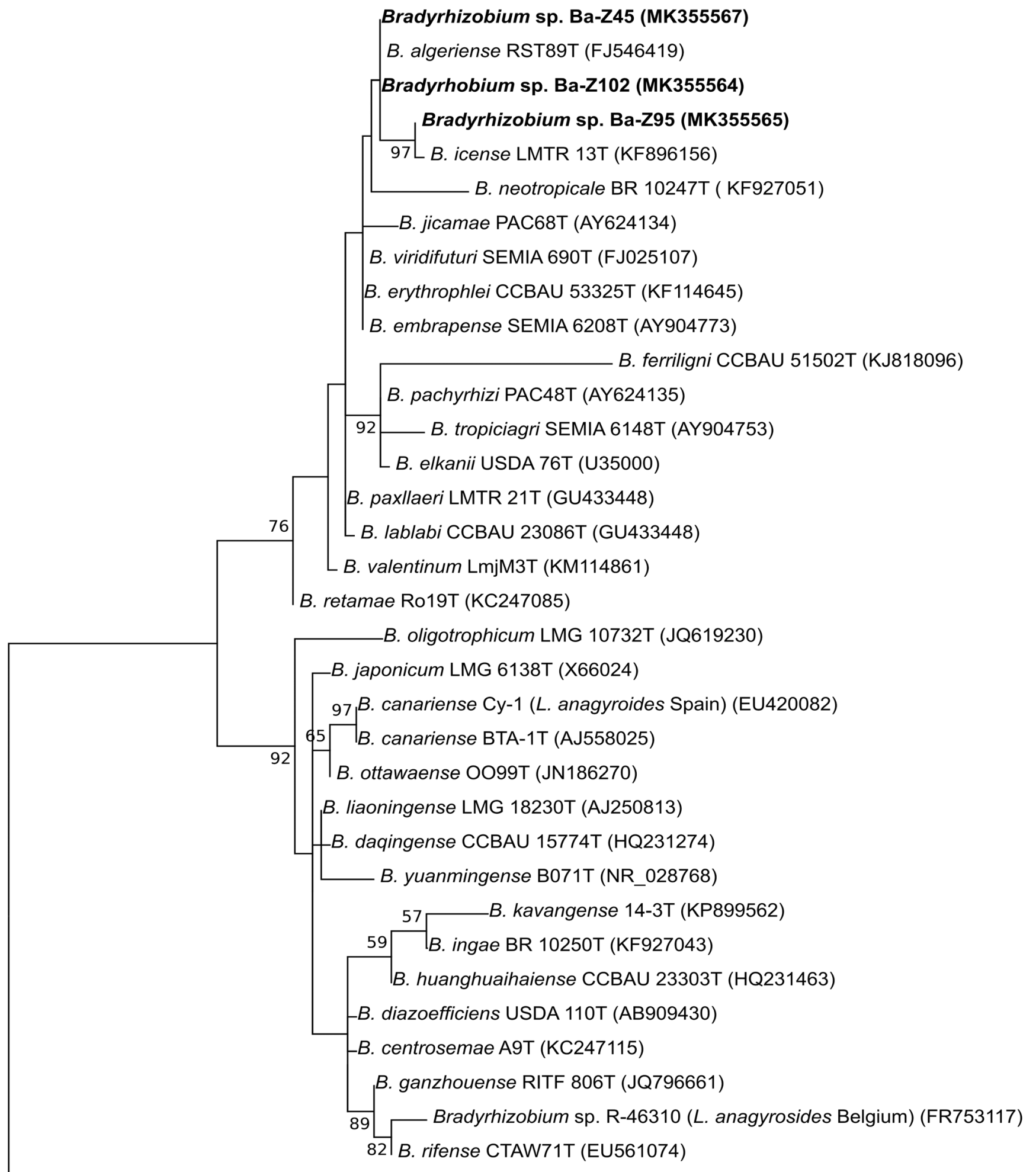

Bosea thiooxidans DSM 9653 (NR 041994)

$$
0.01
$$

Fig. 3 Maximum likelihood tree showing the phylogenetic relationships of the L. anagyroides symbionts studied (bolded) with Bradyrhizobium type strains of recognized species based on 16S rDNA sequences. Bootstrap values based on 1000 replicates $>50 \%$ are indicated at the branching points 
Fig. 4 Maximum likelihood tree showing the phylogenetic relationships of the L. anagyroides symbionts studied (bolded) with Bradyrhizobium type strains of recognized species based on concatenated recA, $a t p D, g \ln I I$, and $d n a K$ gene sequences. Bootstrap values based on 1000 replicates $>70 \%$ are indicated at the branching points. The scale bar presents the number of nucleotide substitutions per site. The GenBank accession numbers for all used gene sequences are given in Fig. S1-S4

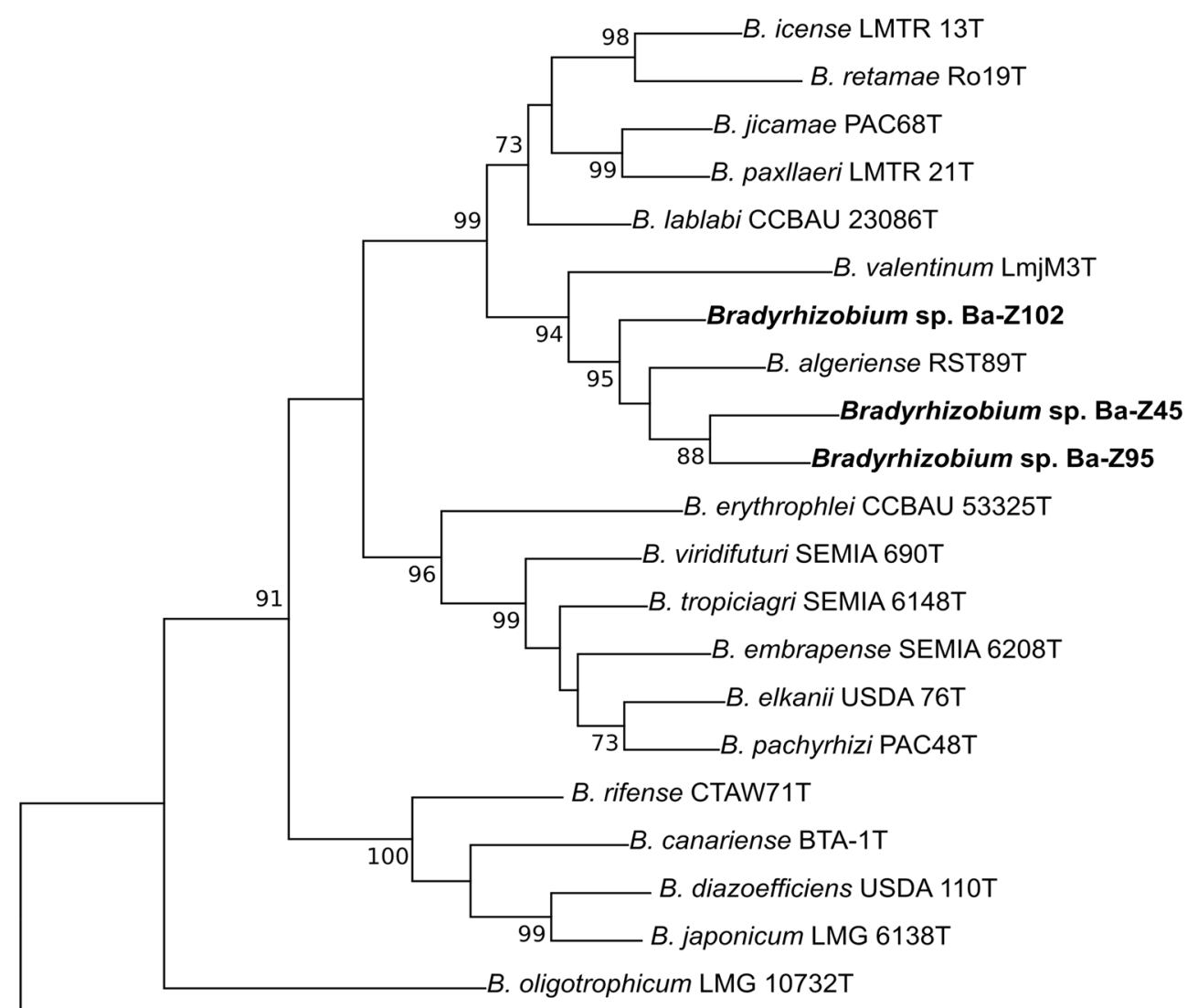

S. etli CFN 42T

$\longmapsto 0.02$

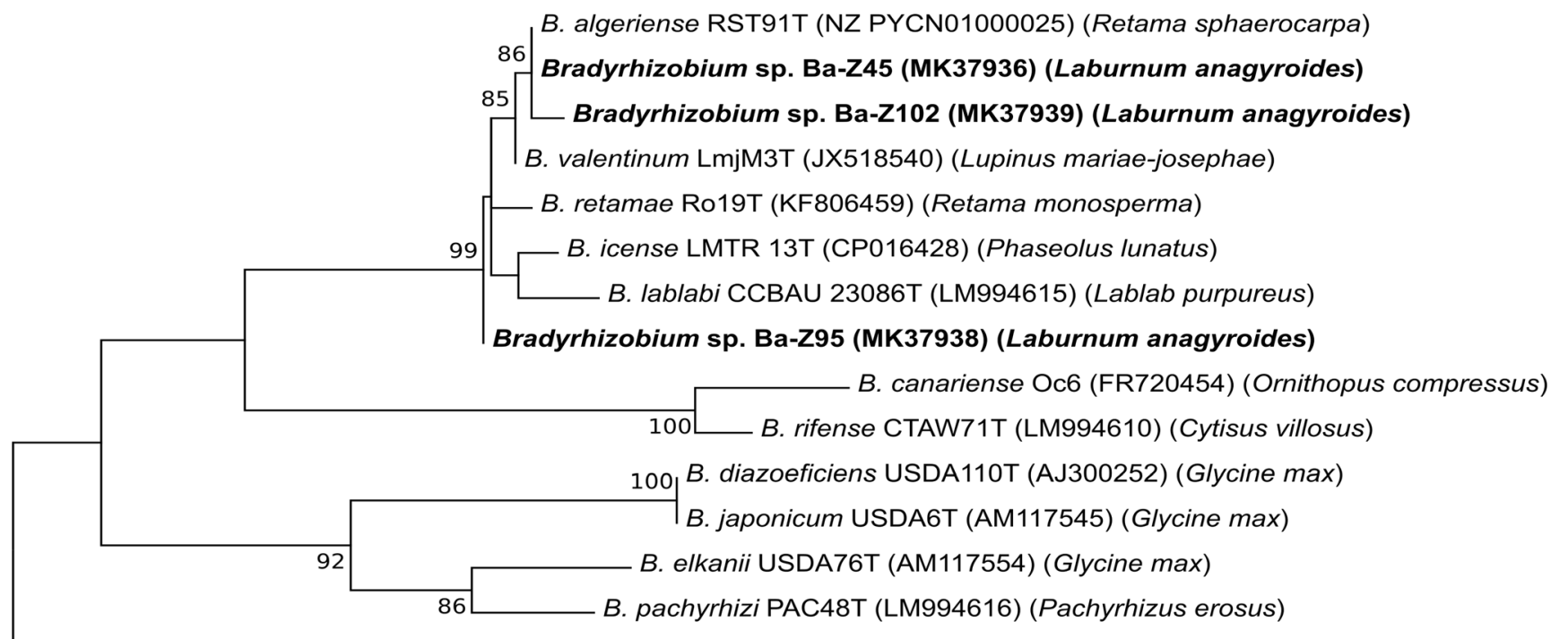

S. meliloti (AF038577) (Medicago sativa)

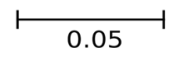

Fig. 5 Maximum likelihood tree showing the phylogenetic relationships of the L. anagyroides symbionts studied (bolded) with Bradyrhizobium type strains of recognized based on nodA gene sequences. Bootstrap values based on 1000 replicates $>70 \%$ are indicated at the branching points. The scale bar presents the number of nucleotide substitutions per site 


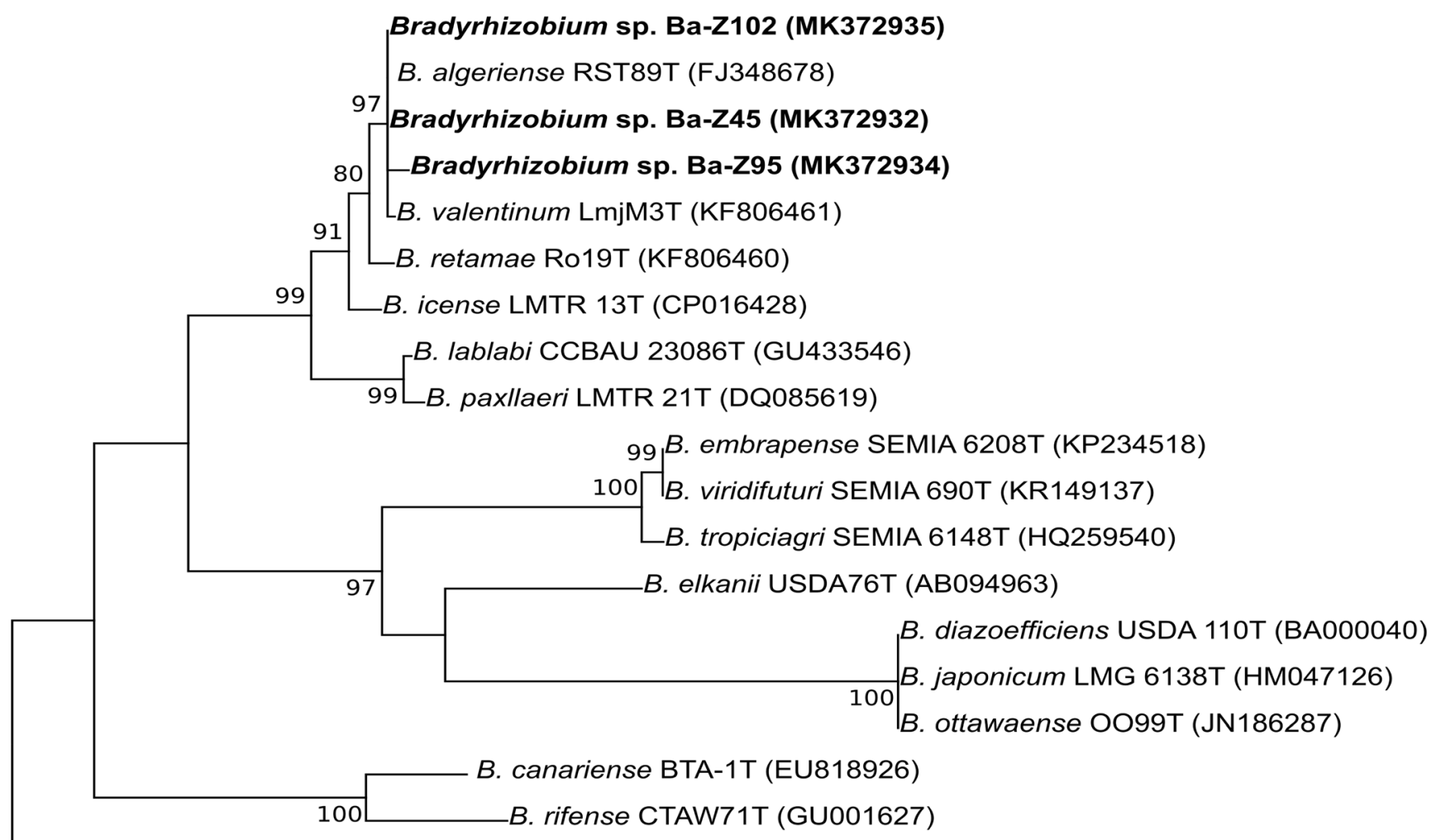

S. etli CFN 42T (NC_004041)

0.05

Fig. 6 Maximum likelihood tree showing the phylogenetic relationships of the L. anagyroides symbionts studied (bolded) with Bradyrhizobium type strains of recognized based on nifH gene sequences.

phylogenetic analysis of the 16S rDNA sequences (Fig. 3) showed that the tested L. anagyroides nodule isolates were members of the Bradyrhizobium genus with affinity to strains referred to as the $B$. jicamae supergroup (Avontuur et al. 2019). The previous studies have shown that the B. jicamae supergroup strains are relatively rare and their geographic range covers mainly hot and arid areas all over the world (e.g. Durán et al. 2014; Ahnia et al. 2018; Boulila et al. 2009). In contrast, the sequences of $L$. anagyroides endosymbionts from Belgium (De Meyer et al. 2011) and Spain (RuizDíez et al. 2009) are grouped with 16S rDNA sequences of Bradyrhizobium japonicum supergroup, pointing to their phylogenetic separateness from the bradyrhizobia isolated in Poland (Fig. 3). Likewise, the prevalence of the B. japonicum supergroup strains among Genisteae bradyrhizobia derived from Central and Northern Europe was indicated in earlier studies (Stępkowski et al. 2018). Therefore, identification L. anagyroides symbionts inhabiting areas of the temperate climate, which markedly differs from the Mediterranean climate, as members of the B. jicamae supergroup, suggest that the legume host, but not the climate type, is a crucial element in the process of the dissemination
Bootstrap values based on 1000 replicates $>70 \%$ are indicated at the branching points. The scale bar presents the number of nucleotide substitutions per site

of the studied bacterial strains. It has been established that human-mediated transport of legume plants, especially seeds, plays an increasingly important role in the process of spreading particular groups of rhizobia, although it was earlier concluded that the wide geographic range detected for many bradyrhizobia might also result from natural processes of dispersal (Parker 2015).

Since the diversity in the 16S rRNA gene sequences of bradyrhizobia is too low to detect differences among species and distinguish them, the recA, dnaK, atpD, and glnA genes were sequenced subsequently to provide more discriminatory analysis of the tested L. anagyroides endosymbionts. It is generally accepted that these protein-coding genes with faster evolution rates than those of the 16S rRNA gene are alternative taxonomic markers for easy and reliable identification of bacterial isolates as well as species delineation replacing DNA:DNA hybridization (Stackebrandt et al. 2002; Glaeser and Kämpfer 2015). Multilocus sequence analysis (MLSA) encompassing combined analysis of several housekeeping genes has been widely used in studies with bradyrhizobia (e.g. Stepkowski et al. 2005; Menna et al. 2009; Lindström et al. 2015; Kalita and Małek 2017). In our studies, the 
taxonomic affiliations of the tested strains were analyzed by MLSA according to the scheme introduced by Menna and Hungria (2011) to establish the phylogenetic relations of diverse collections of Bradyrhizobium strains. Phylogenies were inferred for each $a t p D$, dnaK, glnII, and recA loci separately (Fig. S1-S4) and for combined gene sequences (Fig. 4). In the case of housekeeping genes, their similarity values for the tested strains were much lower compared to those of the $16 \mathrm{~S}$ rRNA gene sequences, which were identical or almost identical. However, it was earlier found that $16 \mathrm{~S}$ rDNA could be identical among closely related species from the genus Bradyrhizobium (Degefu et al. 2018). Based on the highlevel similarity of housekeeping gene sequences and the independent phylogenetic position of the tested strains along with the $B$. algeriense RST89 ${ }^{\mathrm{T}}$, recovered by MLSA, it is reasonable to regard $B$. algeriense as the closest phylogenetic neighbor of the tested isolates. However, MLSA revealed that the strains Ba-Z45, Ba-Z95, and Ba-Z102, representatives of the three groups delineated by BOX-PCR and ITS-RFLP, represent distinct evolutionary lineages, well differentiated from the currently named species. In fact, the values of the nucleotide identity of the concatenated sequences of recA, dnaK, atpD, and $g \ln I I$ between each other and $B$. algeriense ${\text { RST } 89^{\mathrm{T}}}^{(95-96 \%)}$ were not higher than those between the type strain of the other recognized species, e.g. B. icense LMTR $13^{\mathrm{T}} /$ B. retamae Ro $19^{\mathrm{T}}(95 \%)$, B. viridifuturi SEMIA $690^{\mathrm{T}} / B$. tropiciagri SEMIA $6148^{\mathrm{T}}(96 \%)$, and $B$. embrapense SEMIA $6208^{\mathrm{T}} / B$. tropiciagri SEMIA $6148^{\mathrm{T}}(96 \%)$. Therefore, the tested L. anagyroides isolates might form a novel Bradyrhizobium species, but this should be confirmed by genomic data. In fact, due to the growing availability of genomes for rhizobia, MLSA has now been superseded by ANI comparisons between genomes, which has been proven to be adequate for taxonomic purposes (de Lajudie et al. 2019). Nevertheless, MLSA supports many phylogenetic relationships recovered in the genome-based phylogeny for Bradyrhizobium (Avontuur et al. 2019). Unfortunately, there is no defined MLSA threshold to identify bacteria at the species or genus level in rhizobia, in contrast to some other groups of bacteria, e.g. Xenorhabdus (Tailliez et al. 2010) or Bacillus (Liu et al. 2017). However, progress is expected in the next few years related to development of an online database of MLSA allowing comparison of genomic sequences for fast phylogenetic and taxonomic studies of bradyrhizobia (Azevedo et al. 2015).

The studied strains were confirmed to be closely associated with $B$. algeriense and $B$. valentinum, i.e. two species comprising nodule endosymbionts of Genisteae legumes Retama sphaerocarpa and Lupinus mariae-josephae, respectively, which grow solely in the Mediterranean (Durán et al. 2014; Ahnia et al. 2018). Additionally, a tight relationship was also found between the tested isolates and Bradyrhizobium strains nodulating wild genistoid legume shrubs Calicotome spinosa and Spartium junceum growing in the same region (Cardinale et al. 2008; Salmi et al. 2018). In our plant nodulation tests, the isolates were able to establish effective symbiosis with the native host $L$. anagyroides as well as $C$. arborescens and L. polyphyllus, but not with G. max, which was in line with the report by Ahnia et al. (2018). The data described indicate that these bacteria are not strictly specialized towards nodulation of specific plant hosts. In fact, the promiscuous type of symbiosis, widespread among bradyrhizobia, is regarded to be more ancestral than the host-limited symbiosis restricted to specific niches, which may be a result of coevolutionary relationships between microsymbionts and the host plant (Perret et al. 2000).

Unfortunately, not all L. anagyroides symbionts isolated earlier were included in the phylogenetic analysis due to the lack of complete sequence data. However, as illustrated in the dnaK and recA phylogenetic trees (Fig. S2, S3), the tested isolates, especially Ba-Z95, showed phylogenetic affinity to Bradyrhizobium spp. strains isolated from nodules of $L$. anagyroides in Croatia, in contrast to endosymbionts isolated from $L$. anagyroides nodules growing in Belgium and Spain, classified as B. canariense and Bradyrhizobium sp., respectively (Fig. 3).

Symbiotic genes are usually studied in polyphasic rhizobial research, since they allow verification of the nodulation and nitrogen fixation ability. Bacteria in the genus Bradyrhizobium have symbiotic genes displaying a high level of diversity and a different evolutionary history from their housekeeping genes, which suggests their acquisition by lateral gene transfer (LGT) (Menna and Hungria 2011; Lindström et al. 2015; Hungria et al. 2015). It has been reported that sequence analysis of nodA and nifH genes can be useful to examine the symbiotic diversity of Bradyrhizobium strains and elucidate the role of LGT in inheritance of the symbiotic loci (Degefu et al. 2018). The phylogenetic studies of nodA and nifH symbiotic genes, which revealed 16 major clades in the genus Bradyrhizobium, have facilitated the development of the phylogeographic framework for this group of bacteria (Beukes et al. 2016; Stępkowski et al. 2018). In our study the clustering results of the $\operatorname{nodA}$ sequences of the tested isolates were essentially similar to those obtained from the nifH gene sequence analysis (Figs. 5 and 6), but slightly different from the results of the analysis of housekeeping genes (Fig. 4). Following the classification scheme described for symbiotic genes of Bradyrhizobium symbionts, the strains nodulating $L$. anagyroides in Poland, like all other B. jicamae supergroup strains, appear to belong to a group referred to as Clade IV (Beukes et al. 2016).

Moreover, the phylogenetic analysis of $\operatorname{nodA}$ and nifH gene sequences allowed a conclusion that the studied $L$. anagyroides nodule isolates are part of the symbiovar retamae. This symbiovar is represented by $B$. retamae, $B$. algeriense, and $B$. valentinum nodulating Retama 
spp., R. sphaerocarpa, and L. mariae-josephae, respectively (Guerrouj et al. 2013; Durán et al. 2014; Ahnia et al. 2018). The differences in the symbiotic and core gene phylogenies as well as the average nucleotide identity (ANI) values suggest that the symbiotic genes of rhizobia from the symbiovar retamae have been horizontally transferred among different species (Ahnia et al. 2018). Multiple symbiovars, distinguishing symbiotic capabilities of rhizobia, presented within the same host suggest the promiscuity of legume species. Despite the lack of full sequence data of the symbiotic genes from other $L$. anagyroides symbiotic strains, it can be concluded that in its root nodules, L. anagyroides can harbor endosymbionts belonging to different symbiovar types, at least glycinearum (Bradyrhizobium sp. R-46310), genistearum (B. canariense), and retamae (the strains isolated in Poland). It was also reported by De Meyer et al. (2011) that $L$. anagyroides, like most of the other exotic legumes growing in Belgium, is a highly promiscuous host plant engaged in symbioses with indigenous rhizobia nodulating native legumes. This promiscuity could increase its ability to spread into new habitats; hence, $L$. anagyroides seems to be a good candidate for revegetation purposes. Together, our findings provide useful information on identification of the rhizobial partner of L. anagyroides, a legume originating from Southern Europe that has expanded its range into Poland. This is a necessary step for further research addressing ecological and evolutionary processes that shape these particular mutualistic relationships.

Acknowledgements The authors wish to thank dr Waldemar Kazimierczak for technical assistance.

Funding information This work was supported by the Polish Ministry of Science and Higher Education grant for statutory activity (8028) and European Union from the European Regional Development Fund under the Operational Programme Development of Eastern Poland 2007-2013 (POPW.01.03.00-06-003/09-00).

Open Access This article is licensed under a Creative Commons Attribution 4.0 International License, which permits use, sharing, adaptation, distribution and reproduction in any medium or format, as long as you give appropriate credit to the original author(s) and the source, provide a link to the Creative Commons licence, and indicate if changes were made. The images or other third party material in this article are included in the article's Creative Commons licence, unless indicated otherwise in a credit line to the material. If material is not included in the article's Creative Commons licence and your intended use is not permitted by statutory regulation or exceeds the permitted use, you will need to obtain permission directly from the copyright holder. To view a copy of this licence, visit http://creativecommons.org/licenses/by/4.0/.

\section{References}

Adams MA, Simon J, Pfautsch S (2010) Woody legumes: a (re)view from the south. Tree Physiol 30:1072-1082

Ahnia H, Bourebaba Y, Durán D, Boulila F, Palacios JM, Rey L, RuizArgüeso T, Boulila A, Imperial J (2018) Bradyrhizobium algeriense sp. nov., a novel species isolated from effective nodules of Retama sphaerocarpa from northeastern Algeria. Syst Appl Microbiol 41: 333-339

Avontuur JR, Palmer M, Beukes CW, Chan WY, Coetzee MPA, Blom J, Stępkowski T, Kyrpides NC, Woyke T, Shapiro N, Whitman WB, Stephanus N, Venter S, Steenkamp ET (2019) Genome-informed Bradyrhizobium taxonomy: where to from here? Syst Appl Microbiol 42(4):427-439

Azevedo H, Lopes F, Silla P, Hungria M (2015) A database for the taxonomic and phylogenetic identification of the genus Bradyrhizobium using multilocus sequence analysis. BMC Genomics 16(Suppl. 5):S10

Beukes CW, Stępkowski T, Venter SN, Cłapa T, Phalane FL, le Roux MM, Steenkamp ET (2016) Crotalarieae and Genisteae of the south African great escarpment are nodulated by novel Bradyrhizobium species with unique and diverse symbiotic loci. Mol Phylogenet Evol 100:206-218

Boulila F, Depret G, Boulila A, Belhadi D, Benallaoua S, Laguerre G (2009) Retama species growing in different ecological-climatic areas of northeastern Algeria have a narrow range of rhizobia that form a novel phylogenetic clade within the Bradyrhizobium genus. Syst Appl Microbiol 32(4):245-255

Cardinale M, Lanza A, Bonnì ML, Marsala S, Puglia AM, Quatrini P (2008) Diversity of rhizobia nodulating wild shrubs of Sicily and some neighbouring islands. Arch Microbiol 190:461-470

Cardoso AA, Andraus MP, Borba TC, Martin-Didonet CC, Ferreira EP (2017) Characterization of rhizobia isolates obtained from nodules of wild genotypes of common bean. J Microbiol 48:43-50

Castro D, Urzúa J, Rodriguez-Malebran M, Inostroza-Blancheteau C, Ibánez C (2017) Woody leguminous trees: new uses for sustainable development of drylands. J Sustainable For 36:764-786

Chang Y, Wang JY, Wang ET, Liu HC, Sui XH, Chen WX (2011) Braydrhizobium labiabi sp. nov. isolated from effective nodules of Labiab purpureus and Arachts hypogaea. Int J Syst Evol Microbiol 61:2496-2502

de Lajudie PM, Andrews M, Ardley J, Eardly B, Jumas-Bilak E, Kuzmanović N, Lassalle F, Lindström K, Mhamdi R, MartínezRomero E, Moulin L, Mousavi SA, Nesme X, Peix A, Puławska J, Steenkamp E, Stępkowski T, Tian CF, Vinuesa P, Wei G, Willems A, Zilli J, Young P (2019) Minimal standards for the description of new genera and species of rhizobia and agrobacteria. Int J Syst Evol Microbiol 69(7):1852-1863

De Meyer SE, van Hoorde K, Vekeman B, Braeckman T, Willems A (2011) Genetic diversity of rhizobia associated with indigenous legumes in different regions of Flanders (Belgium) soil. Biol Biochem 43:2384-2396

Degefu T, Wolde-Meskel E, Rasche F (2018) Genetic diversity and symbiotic effectiveness of Bradyrhizobium strains nodulating selected annual grain legumes growing in Ethiopia. Int J Syst Evol Microbiol 68:449-460

Durán D, Rey L, Navarro A, Busquets A, Imperial J, Ruiz-Argüeso T (2014) Bradyrhizobium valentinum sp. nov., isolated from effective nodules of Lupinus mariae-josephae, a lupine endemic of basic-lime soils in eastern Spain. Syst Appl Microbiol 37:336-341

Glaeser S, Kämpfer P (2015) Multilocus sequence analysis (MLSA) in prokaryotic taxonomy. Syst Appl Microbiol 38:237-245

Guerrouj K, Ruíz-Díez B, Chahboune R, Ramírez-Bahena MH, Abdelmoumen H, Quiñones MA, El Idrissi MM, Velázquez E, Fernández-Pascual M, Bedmar EJ, Peix A (2013) Definition of a 
novel (sv. retamae) within Bradyrhizobium retamae sp.nov., nodulating Retama sphaerocarpa and Retama monosperma. Syst Appl Microbiol 36:218-223

Hoagland DR, Arnon AH (1950) The water culture method for growing plants without soil. California Agri Exp Stat Circ 347:1-32

Hungria M, Menna P, Delamuta JR (2015) Bradyrhizobium, the ancestor of all rhizobia: phylogeny of housekeeping and nitrogen-fixation genes. In: de Bruijn FJ (ed) Biological Nitrogen Fixation, vol 1. Wiley, Hoboken, pp 191-202

Jordan DC (1982) Transfer of Rhizobium japonicum Buchanan 1980 to Bradyrhizobium gen. nov., a genus of slow-growing, root nodule bacteria from leguminous plants. Int J Syst Bacteriol 32:136-139

Kalita M, Małek W (2017) Molecular phylogeny of Bradyrhizobium bacteria isolated from root nodules of tribe Genisteae plants growing in Southeast Poland. Syst Appl Microbiol 40:482-491

Kaschuk G, Hungria M, Andrade DS, Campo RJ (2006) Genetic diversity of rhizobia associated with common bean (Phaseolus vulgaris L.) grown under no-tillage and conventional systems in southern Brazil. Appl Soil Ecol 32:210-220

Koeuth T, Versalovic J, Lupski JR (1995) Differential subsequence conservation of interspersed repetitive Streptococcus pneumoniae BOX elements in diverse bacteria. Genome Res 5:408-418

Laguerre G, Mavingui P, Allard MR, Charnay MP, Louvrier P, Mazurier SI, Rigottier-Gols L, Amarger N (1996) Typing of rhizobia by PCR DNA fingerprinting and PCR-restriction fragment length polymorphism analysis of chromosomal and symbiotic gene regions: application to Rhizobium leguminosarum and its different biovars. Appl Environ Microbiol 62:2029-2036

Lindström K, Aserse A, Mousavi SA (2015) Evolution and taxonomy of nitrogen-fixing organisms with emphasis on rhizobia. In: Bruijn FJ (ed) Biological Nitrogen Fixation, vol 1. Wiley, pp 21-38

Liu Y, Lai Q, Du J, Shao Z (2017) Genetic diversity and population structure of the Bacillus cereus group bacteria from diverse marine environments. Sci Rep 7(1):689

Menna P, Hungria M (2011) Phylogeny of nodulation and nitrogenfixation genes in Bradyrhizobium: supporting evidence for the theory of monophyletic origin, and spread and maintenance by both horizontal and vertical transfer. Int J Syst Evol Microbiol 61:30523067

Menna P, Barcellos FG, Hungria M (2009) Phylogeny and taxonomy of a diverse collection of Bradyrhizobium strains based on multilocus sequence analysis of the $16 \mathrm{~S}$ rRNA gene, ITS region and $g \ln I I$, recA, atpD and dnaK genes. Int J Syst Evol Microbiol 59:29342950

Ormeño-Orrillo E, Martínez-Romero EA (2019) Genomotaxonomy wiew of the Bradyrhizobium genus. Front Microbiol 10:1334

Parker MA (2015) The spread of Bradyrhizobium lineages across host legume clades: from Abarema to Zygia. Microb Ecol 69:630-640

Perret X, Staehelin C, Broughton WJ (2000) Molecular basis of symbiotic promiscuity. Microbiol. Mol Biol Rev 64:180-201

Ruiz-Díez B, Fajardo S, Puertas-Mejía MA, de Felipe MR, FernándezPascual M (2009) Stress tolerance, genetic analysis and symbiotic properties of root-nodulating bacteria isolated from Mediterranean leguminous shrubs in Central Spain. Arch Microbiol 191:35-46

Sachs JL, Kembel SW, Lau AH, Simms EL (2009) In situ phylogenetic structure and diversity of wild Bradyrhizobium communities. Appl Environ Microbiol 75:4727-4735

Salmi A, Boulila F, Bourebaba Y, Le Roux C, Belhadi D, de Lajudie P (2018) Phylogenetic diversity of Bradyrhizobium strains nodulating
Calicotome spinosa in the northeast of Algeria. Syst Appl Microbiol 41:452-459

Shamseldin A, Abdelkhalek A, Sadowsky MJ (2017) Recent changes to the classification of symbiotic, nitrogen-fixing, legume-associating bacteria: a review. Symbiosis 71:91-109

Sneath PHA, Sokal RR (1973) Numerical taxonomy. The principles and practice of numerical classification. Cabi, San Francisco

Somasegaran P, Hoben HJ (1994) Handbook for rhizobia. Springer, Verlag, Berlin

Stackebrandt E, Frederiksen W, Garrity GM, Grimont PA, Kämpfer P, Maiden MC, Nesme X, Rosselló-Mora R, Swings J, Trüper HG, Vauterin L, Ward AC, Whitman WB (2002) Report of the ad hoc committee for the re-evaluation of the species definition in bacteriology. Int J Syst Evol Microbiol 52:1043-1047

Stępkowski T, Moulin L, Krzyzanska A, McInnes A, Law IJ, Howieson J (2005) European origin of Bradyrhizobium populations infecting lupins and serradella in soils of Western Australia and South Africa. Appl Environ Microbiol 71:7041-7052

Stępkowski T, Banasiewicz J, Granada KE, Andrews M, Passaglia LMP (2018) Phylogeny and phylogeography of rhizobial symbionts nodulating legumes of the tribe Genisteae. Genes 9:163-188

Tailliez P, Laroui C, Ginibre N, Paule A, Pagès S, Boemare N (2010) Phylogeny of Photorhabdus and Xenorhabdus based on universally conserved protein-coding sequences and implications for the taxonomy of these two genera. Proposal of new taxa: $X$. vietnamensis sp. nov., P. luminescens subsp. caribbeanensis subsp. nov., $P$. luminescens subsp. hainanensis subsp. nov., P. temperata subsp. khanii subsp. nov., $P$. temperata subsp. tasmaniensis subsp. nov., and the reclassification of $P$. luminescens subsp. thracensis as P. temperata subsp. thracensis comb. nov. J Syst Evol Microbiol 60:1921-1937

Tamura K, Stecher G, Peterson D, Filipski A, Kumar S (2013) MEGA6: molecular evolutionary genetics analysis version 6.0. Mol Biol Evol 30:2725-2729

Tindall BJ, Rosselló-Móra R, Busse HJ, Ludwig W, Kämpfer P (2010) Notes on the characterization of prokaryote strains for taxonomic purposes. Int J Syst Evol Microbiol 60:249-266

Vanlnsberghe D, Maas KR, Cardenas E, Strachan CR, Hallam SJ, Mohn WW (2015) Non-symbiotic Bradyrhizobium ecotypes dominate north American forest soils. ISME J 9:2435-2441

Versalovic J, Schneider GM, Bruijn F, Lupski JR (1994) Genomic fingerprint of bacteria using repetitive sequence-based polymerase chain reaction. Methods Mol Cell Biol 5:25-40

Vincent JM (1970) Manual for the practical study of the root-nodule bacteria. JBP Handbook 15, Blackwell, Oxford

Yao Y, Wan R, Lu JK, Sui XH, Wang ET, Chen WX (2014) Genetic diversity and evolution of Bradyrhizobium populations nodulating Erythrophleum fordii, an evergreen tree indigenous to the southern subtropical region of China. Appl Environ Microbiol 80:6184-6194

Yarza P, Yilmaz P, Pruesse E, Glöckner FO, Ludwig W, Schleifer KH, Whitman WB, Euzéby J, Amann R, Rosselló-Móra R (2014) Uniting the classification of cultured and uncultured bacteria and archaea using 16S rRNA gene sequences. Nat Rev Microbiol 12: 635-645

Publisher's note Springer Nature remains neutral with regard to jurisdictional claims in published maps and institutional affiliations. 